\title{
Writing for International Journals: Lessons Learned from the Experts
}

\author{
Urip Sulistiyo ${ }^{1,{ }^{*}}$ Reny Heyanti ${ }^{2}$, Kaspul Anwar ${ }^{3}$, Yuzadi Yuzadi ${ }^{4}$, Mifthahul \\ Nurzanah $^{5}$ \\ ${ }^{1245}$ Universitas Jambi, Jambi, Indonesia \\ ${ }^{3}$ Institut Agama Islam Muhammad Azim Jambi, Indonesia \\ ${ }^{*}$ Corresponding author. Email: urip.sulistiyo@unja.ac.id
}

\begin{abstract}
This study investigated how to publish a journal article in reputable International Journals. A descriptive qualitative approach was used to gather the data from the expert participants. A semi-structural interview was conducted and 5 expert participants participated in the data collection phase. The research findings show that four themes came up; the reasons why a journal manuscript was rejected, the benefit of workshop to improve writing skills, the importance of the journal article writing guide book, and the technical issues in the journal article writing process. Regarding the importance of journal publication among the educators and researchers, it is better for the University in collaboration with government and stakeholders to provide a workshop as well as the guideline book which will help educators and researchers to write the international journal article.
\end{abstract}

Keywords: Writing, International Journal.

\section{INTRODUCTION}

Director of Intellectual Property Management of the Ministry of Research and Higher Education (KEMENRISTEKDIKTI), in his foreword [1] said that the scientific publication in the journal International reputable is one of the outer research and an indicator of research success. This publication is also thought to be a part and proof of the performance of both colleges and R \& D institutions in the effort to reach World Class University and World Class Research Institution. To realize that, the need to publish research results has been very urgent and become a mandatory thing. This is in line with the release of the circular of the Director general of Higher Education number 152year 2012 requiring each undergraduate (S1), Magister (S2) and doctoral (S3) students to publish their research prior their final exam to graduate from the program accredited national Journals and International Journals.

By referring on the quantity, according to Amelia Mia \& Rizka Rahmaida [2], the Indonesian scientific publications on international journals from year to year continue to show a very significant improvement trend. This rising trend can be seen from the graphics provided by (Kemenristekdikti) [3], on the Portal SINTA website (Fig. 1). In that graphic it can be seen that the increase in Indonesian scientific publications in international journals is in second place after Malaysia and above Singapore. Nevertheless, according to Lukman et al., [1] based on the data derived from Scopus, the number of Indonesian publications indexed in Scopus period from 2010 to April 2016 amounted to 29. 624 articles. The Indonesian international publication of the Web of Science (Thomson) in the same period amounted to 17,636 articles in the same position, under Malaysia and Thailand and above the Philippines. The comparison of international scholarly publications between Indonesia, Malaysia and Thailand between the 2010-2016 period is very lame. "It proves that researchers in Malaysia and Thailand are much more productive in producing international scientific publications than with Indonesian researchers" [1]. 


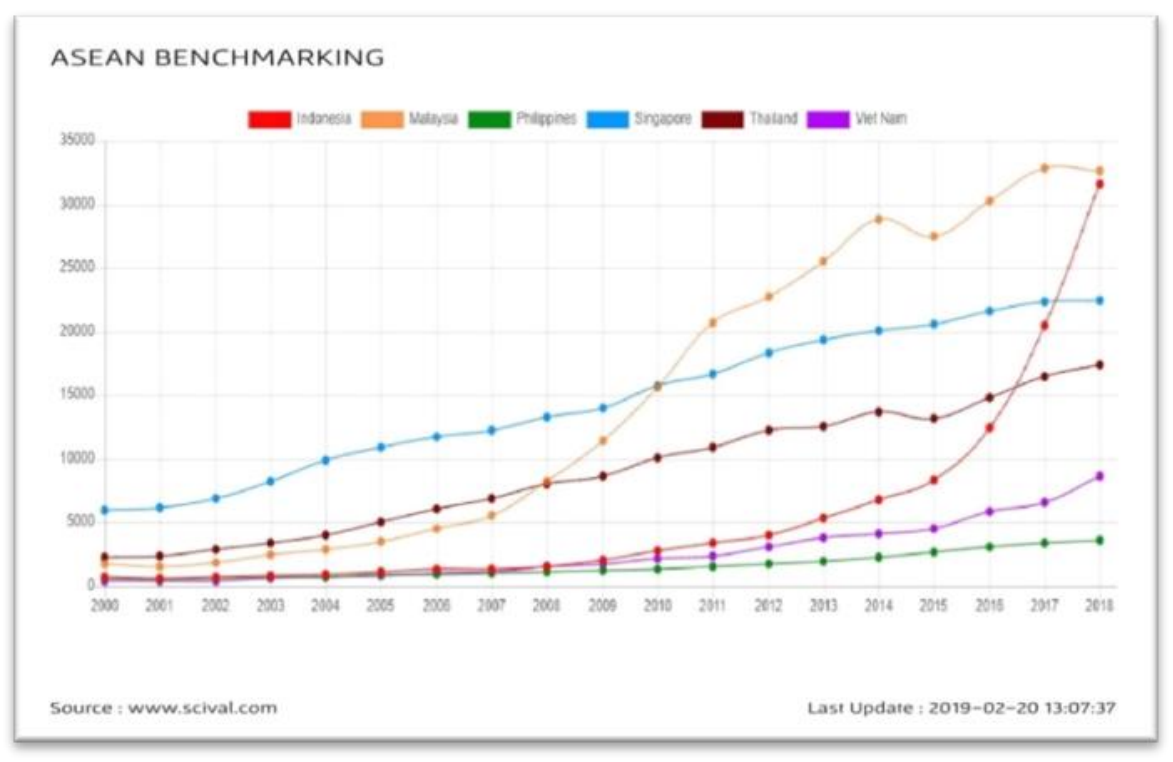

Figure 1. ASEAN Benchmarking

Lukman et al., [1] explained that the low number of Indonesian scientific publications on internationalreputable journals is due to several factors. Among them, lack of reference access for writing publications; Limited research facilities; At least research collaborations; Unavailability of international publication supervision; there are only few journals in Indonesia which are internationally reputable. In addition, based on the search in Scimago[4], The number of Indonesian journals entering the International Journals indexed in Scopus and Web of Science is 37 journals. Furthermore, in addition to the five points above, other problems that are the cause of the limited number of Indonesian scientific publications at the international level are also due to the cost factor and incentive for publication in international reputable journals.

Several researches have been conducted related to writing for an international journal article. For instance, Subekti[5] focused on finding the information on a number of reputable journal databases, he concluded that the scientific publications of Indonesian researchers in international journals are reputable in the category of concern. The other interesting study was done by Husin \& Nurbayani,[6] who examined the ability of Indonesian students to write academic papers. Through the analysis of student surveys and lecturer interviews, it is found that the main problem faced by students in writing articles or scientific publications was the aspect of English proficiency, the development of writing content, and the writing techniques are still category. They even affirm that the aspect of English proficiency is the most decisive aspect to improve students' ability to write scientific articles. In order to solve the problems regarding the lack of publication published by Indonesian researchers in international journals, the current study focuses on investigating the experts' view on their experiences in publishing the international journal article.

\section{LITERATURE REVIEW}

Regarding to writing a journal article and its publication process, it was revealed that the process itself came out for various motivations and reasons from the writer. In line with this, Rezaei \& Seyri [7] proven that the writer intends to write a journal article for some reasons such as for academic requirements, for better self-resume and sharing knowledge to the world. In terms of academic requirements, it is well-known for most educational institutions which regulate their students to write and publish some articles before they finish their study in those institutions. Publishing a journal is considered as the requirements before they conduct their own research. Moreover, to make better improvement as academicians, writing a journal article is a crucial thing to do. The more journal publications, the more people get a better track record in professional and academic purposes. It also gives an impressive effect in terms of employment or getting jobs, publishing journals can be taken into consideration.

Furthermore, publishing journals also means for an evaluation system and for sharing. In line with this, Rezaei \& Seyri [7] revealed that for professor and similar professional purposes, the ranking system is evaluated based on the amount of journal publications. Submitting international journals can increase their chance to get promotions [8]. In addition, one of the reasons for publishing international journals is they can easily interact with others in terms of academic purposes and for those who are interested in same research fields. It is positive value for sharing knowledge to everyone on the world level and sharing personal perspectives that can be useful for the science enrichments and wider knowledge contents. 
Not only for getting the promotion, as what Zachrias et al writing for international publication is because of the role of the writer as a writing teacher, so as a writing teacher should have had good writing. Besides that, a writing teacher should also be a critical reading. Another reason that inspires a writer to write is to keep him or her up to date with the current development in the field, for instance, writing for publication is a must for a certified lecturer.

In order of writing journal there is a brief outline of writing journal. Those are: title, title gives the most important part in the journal because the reader wants to read the journal depends on it. The title should be describing the research shortly, informatively and concisely. Then, authors of research should have made a significant contribution in the process of writing the journal. Next is the abstract, in writing the abstract normally consists of background, objective, methods, settings, design, results and conclusion. It consists of 200-250 words. However, different journals have different formats. The keyword is usually 3-10 keywords. This is required to ease the process of indexing and crossreferencing [9].

In addition, in writing a journal IMRAD system becomes the basic of a scientific paper [9] [10]. IMRAD stands for Introduction, Methods, Results and Discussions. In introduction, the writer should describe briefly the background of the study and research question, and the objective and rationale of the study. In method, the writer should describe the context and setting of the study, specify the study design, describe the 'population' (patients, doctors, hospitals, etc.), describe the sampling strategy, describe the intervention (if applicable), identify the main study variables, describe the data collection instruments and procedures, and make the outline analysis methods. In the process of result, the writer should report on data collection and recruitment in terms of response, rate, etc; describing participants (demographic, clinical condition etc), Present key findings with respect to the central research question Present secondary findings (secondary outcomes, subgroup analyses, etc.) [10]. In discussion, it begins with a summary of the main findings, followed by the meaning and implications of these for clinicians or policymakers. Comparison is made with existing literature. Explain exceptions and clarify unsettled points. State the strengths and limitations of the study and implications for future research or clinical practice.[9]. Even though the process that had been told is IMRAD, Ming [9] added in the journal there is a conclusion that is used for summarizing the research.

From those processes, there are the hardest parts that occurred in writing a journal for publication. As the Zachrias[8] et al stated the hardest part in writing for publication is hard to find the current topic and also can appeal to a wider audience, hard to make sure about the topic that inspires the reader, and hard to find the right angle or perspective for writing.

In addition, the process of publishing a journal seems not as simple as people thought. There were some hurdles that happened in the publications process such as political issues, language problems, the priority of the English journal and the lack of instruction. The problems related to the language problems were the most related things that also happen in some countries which do not use English as the first language. They struggle with their work in writing a journal in the English language which is not their main language [7]. In addition, academicians who have not enough training in academic writing also had a hard time. As mentioned by one of the interviewees in Rezaei \& Seyri's works which suggested to educational institutions for providing academic writing training so students understand well how to write well in a journal article. In addition, Rezaei \& Seyri [7] also revealed some strategies that might work to be applied when writing a journal article. The process of writing a journal can be anticipated by some tips such as reading some related journals before writing the new one, consultation with competent supervisors, participating in writing workshops and paying professional editing services for the better result.

\section{METHODS}

Descriptive qualitative was utilized in this study with the interview as the way in collecting the data. Qualitative research in general can be used for research on people's life, history, behavior, concepts or phenomena, social problems, and so on [11]. One of the reasons for using a qualitative approach is to collect data and clearly understand how the experts relate to international journal publications. Descriptive qualitative is the semi-structured interview was delivered to the experts deal with writing International Journal. Four experts which were as the participants involved in this study: $\mathrm{Hn}, \mathrm{Hr}, \mathrm{Rh}$, and $\mathrm{Hd}$.

\begin{tabular}{|c|c|l|}
\hline No & Participant & \multicolumn{1}{|c|}{ Experience } \\
\hline 1. & $\mathrm{Hn}$ & $\begin{array}{l}\text { An international article author who } \\
\text { publishes his works in a number of } \\
\text { International journals }\end{array}$ \\
\hline 2. & $\mathrm{Hr}$ & $\begin{array}{l}\text { Indonesian author who publishes his } \\
\text { works in a number of International } \\
\text { journals }\end{array}$ \\
\hline 3. & $\mathrm{Rh}$ & $\begin{array}{l}\text { Indonesian author who publishes her } \\
\text { works in a number of International } \\
\text { journals }\end{array}$ \\
\hline 4. & $\mathrm{Hd}$ & $\begin{array}{l}\text { Indonesian author who publishes his } \\
\text { works in a number of International } \\
\text { journals }\end{array}$ \\
\hline
\end{tabular}

The interview technique in this study was conducted with using a semi structured method. Semi-structured interviewing is an interview process that uses an interview guide that comes from developing the topic and 
asks questions and is more flexible use than the interview. Interviews were conducted by directly asking expert participants to explore and obtain information related to their journal publications [12]. The interview uses interview guidelines, so that researchers can develop research questions according to the desired information needs.

The interview process is carried out by submitting some of the questions contained in the interview guide. The researcher also added several questions outside of the questions in the interview guide to further deepen the research. Then the data analysis begins with a transcription of the interview. The transcription of the interview will be carried out by the researcher. After writing the interview, the researcher will use coding to identify the themes and patterns of the interview data. [13]

\section{FINDINGS AND DISCUSSION}

\subsection{Reasons the Journal Manuscript Rejected (Interview and Analysis Document)}

There are several reasons why the article was rejected by a reputable international journal. From the results of interviews with sources that have written and published in a reputable international journal, the constraints causing students to fail to be accepted journals are indexed more because of the language. One of the participants responded in the interview as quoted below:

"My writing has been rejected about 3 times. The reason the editors reject is that the English is not good, in terms of grammar, choice of words, or the way of delivering/state of the art of the article rejected " (interview with $\mathrm{Hd}$ )

This means that the English used does not meet the minimum international journal standards. Indeed, English as the language of the scientific article writing in international journals. Therefore, the manuscript that is ready to be delivered to international journals must be fulfilled in good language rules and in accordance with the standards. One way to address this is by translating and proofreading to a professional body or institution that provides this service. In addition to language, another reason is the research scope and the intended journal is not appropriate. This means that the journal selection is the right target to publish researched topics. The interview showed that one of participants' article had been rejected because his research was out of scope of the intended journal. He reveals,

"I once put my writing to a Scopus-indexed journal with the applied Chemistry scope. But the focus of the sub-theme is different. So I guess the reason of rejection because of that. After that I decided not to send the article to that journal " (Interview with $\mathrm{Hr}$ )
So, the step that should be done is to learn intended journal based on the topic and article that have been written and learned the complete guide of intended journal.

In the status of "reviewing" is one of the rejection is because of language problem. Here are examples of review as main language constraints.

\subsection{The Benefit of Workshop}

Workshop held related to the improvement the ability of writing a reputed international journal article systematically gives benefit for authors. With material filter and direct mentoring in the writing manuscript of scientific papers for the publication in international journals, it can motivate writers to remain consistent in writing. One of the respondents in interview results reveals:

"I have participated in a journal-writing training held by LPPM of Jambi University. And this training is very helpful ". (interview with Rh)

Organizing workshop or training of International journal article writing is important to develop the understanding and ability of lecturers in writing articles in the International journal. In more detail, the procurement of this workshop becomes a guide for authors in preparing the article, as well as developing practical skills in the International journal article writing, including new topics that have potential to be submitted in reputable international journals.

\subsection{Constraints and Solutions in Writing Journal Articles}

There are many obstacles that may be faced when writing a journal article. In addition to language problems, the novelty of ideas becomes one of the other obstacles. However, motivation is the main factor for the author to stop or consistently continue the writing until it is completed and submitted. Based on the results of the interview, the main major obstacle faced by the author is the internal motivation.

"I think the biggest obstacle is from us because of lack of intention, persistence, and 'academic picnic '. My personal constraint is to want a good writing but with minimal effort, this is the mindset that I changed. Once done with yourself, the outside factor that is becoming a constraint is looking for the 'storyline 'article that we want to write, a new language barrier ". (interview with $\mathrm{Hn}$ )

To overcome this, the author who once published his writings in the International journal Scopus-indexed, reveals: 
"Addressing personal constraints: fixing intentions, giving time priorities for writing, optimism, and willing to work hard. Overcoming obstacles looking for ' storyline ' and English: Many 'academic picnic ' by reading journals similar to the articles we are about to write. The more reading the better because it can fix English barriers as well. For parties like LPPM can petrify (1) Mentoring in terms of proofreading before being submitted so that the article is not reject only because of language barriers, (2) Access international journals to subscribe or utilize colleagues abroad, (3) develop a journal in its own environment and push towards a reputable journal. "(Interview with $\mathrm{Hn}$ )

From the solutions offered, it can be concluded that motivation plays an important role for the authors to consistently continue the action of the article until the accepted. In addition, workshop and community writing also become one of the places for researchers and writers to do "academic picnic" so that writers can increase their motivation and continually continue the writing. With regards to language problems, many things are done as reading many related journal articles so that indirectly make it easier for authors to know the shape of structures, language patterns and conveyance patterns in the displayed results. In addition, with a lot of reading someone will easily look for ideas to be able to write scientific articles. If language issues are still a major constraint for the authors, then language services can be a solution for writers to still be able to post and publish their writings in reputable international journals.

\subsection{The importance of the guide book for Writing an article}

A Scientific journal article writing guide can be one of the references and guidelines for authors containing information standards, technical and other issues that the author may encounter when preparing their manuscript for reputable international journals. There are many guides that can help the author write a good journal article. Over all, paper formats, writing, and other technical matters relate to language are key points in the journal article Writing Handbook. Generally, and following the standards, the presentation of paper journal articles include title, Abstract, Introduction, literature Review, research methods, results and discussion, and conclusions and implications. From the interview, a participant reveals:

"I once read the journal article writing guidebook, but I forgot the title. But, when I learned from a journal-writing book, the books actually have the same common language, but with varying details according to the author's point of view. However, it does not mean that there is no need to read a lot of books, precisely because of the different details that we need to read about the books on writing journals. Because those details can be a map that matches the article we're going to write ".(Interview with $R h$ )

By referring to the viewpoint of different book candidates that are journal articles that make the international journal as target, can retrieve information and knowledge in the writing of scientific articles according to the problem that they face. In finding the ideas, presenting the data, scientific articles writing systematics, essential information, and other technical matters such as language, table presentation, so on. The handbook will be very useful for the development of a scientific article because there are important guidelines in it that can make a scientific article has the desired standards to be eligible and to be published in international journals Reputable. Through the authors experience of Scopus indexed international journals, writer can learn many things and practice techniques that are important to the development of the journal.

\subsection{Technical Issues in The Journal Article Writing Process}

Cited from an expert resource in the field, here are things that the author can do when he wants to post his writings in a reputable international journal. First, targeting the appropriate journal. Second, navigates what has been searched; research domain, the purpose and the scope of the intended journal, the trusted source to know the earlier publication on the researched issues. Third, understanding the journal genre. Fourth, determines the topic Research and objectives: contribution of research and GAP. Fifth, make preliminary or rational argument. A participant of the study reveals that:

Prior submitting the article we need to make sure that the targeted journal has the right scope with our research topic. Next, navigating the update references is important. Then, we need to look for information about the journal genre or field. Providing a research gap so the editor will consider your article to be published. Your article must be well written in terms of its language use and argumentation you made in it. (Interview with Hn)

At least there are 5 considerations before we decide to submit our paper to the targeted journal. We need to consider the appropriate issues that best fit our research topic. Then, we need to think the journal scope. Next, make sure that we read and understand the journal genre such as for educational field, agricultural setting and so on and so forth. As the authors, we need to provide research gap and contribution 


\section{CONCLUSION AND RECOMMENDATIONS}

Based on the discussion above, there were four essential themes found in this study. The four themes came up based the data analysis: the reasons on why journal manuscript rejected (interview and analysis document), the benefit of workshop to improve writing skills, the importance of the journal article writing guide book, and the technical issues in the journal article writing process. Then, the researcher considers that this research has the weakness. In terms of the participants, the researcher involved only the researchers or the writers as the main respondents, without involved the reviewer or the journal checker to gain and support the data in more detail.

In addition, accordance on the importance of journal publication among the educators, it is better for the higher education cooperate with government and stakeholder to provide workshop as well as associate the guideline book for them who is obligated to write the international journal article. So, the amount of scientific journal published especially from Indonesian authors hopefully will be increased. Then, will contributed the world wide education and research generally, and support the Indonesian authors to contributed in international published journal index specifically.

\section{REFERENCES}

[1] Lukman, Yaniasih, L Maryati, M A Silalahi, \& A Sihombing. (2016). Kekuatan 50 Institusi Ilmiah Indonesia. Retrieved from http://www.dikti.go.id/epustaka/buku-kekuatan-50institusi-ilmiah-indonesia/

[2] M Amelia, \& R Rahmaida. (2017). Produktivitas ilmiah peneliti Indonesia pada penelitian keanekaragaman hayati Indonesia berdasarkan basis data scopus 1990 - 2015 (scientific productivity of Indonesian researcher on Indonesian biodiversity research based on scopus database 1990 - 2015). Jurnal Biologi Indonesia, 13(2), 241-251.

[3] Kemenristekdikti. (2019a). ASEAN BENCHMARKING. Retrieved January 20, 2019, from http://sinta2.ristekdikti.go.id/home/benchmark

[4] Scimago. (2019). Scimago Journal \& Country Rank. Retrieved February 20, 2019, from https://www.scimagojr.com/journalrank.php?count ry $=$ ID\&wos $=$ false

[5] N B Subekti, (2015, April 13). Rangking Publikasi Ilmiah Internasional Indonesia. Sindo, pp. 1-3. Retrieved from https://nasional.sindonews.com/read/988644/162/ra ngking-publikasi-ilmiah-internasional-indonesia1428903924
[6] M S Husin. \& E Nurbayani. (2018). The Ability of Indonesian EFL Learners in Writing Academic Papers. Dinamika Ilmu, 17(2), 237-250. https://doi.org/10.21093/di.v17i2.725

[7] S Rezaei, and H Seyri. (2019). "Iranian Doctoral Students' Perceptions of Publication in English.”. www.emeraldinsight.com/2050-7003.htm

[8] N T Zacharias,, H P. Widodo, and WA. Renandya. n.d. (201) "Writing for International Publication": An Interview With." 115-29. TEFLIN Journal, Volume 23, Number 2,

[9] K E Ming. (2006). "How To Write A Journal Article ?" 1(2):86-87

[10] T V Perneger, and P M Hudelson. (2004). "Writing a Research Article : Advice." 16(3):191-92.

[11] J W Creswell \& C N Poth. (2016). Qualitative inquiry and research design: Choosing among five approaches. Sage publications.

[12] J Corbin \& A Strauss, (2014). Basics of qualitative research: Techniques and procedures for developing grounded theory. Sage publications.

[13] P Bazeley, \& K Jackson, (2013). Qualitative data analysis with NVivo. SAGE publications limited. 